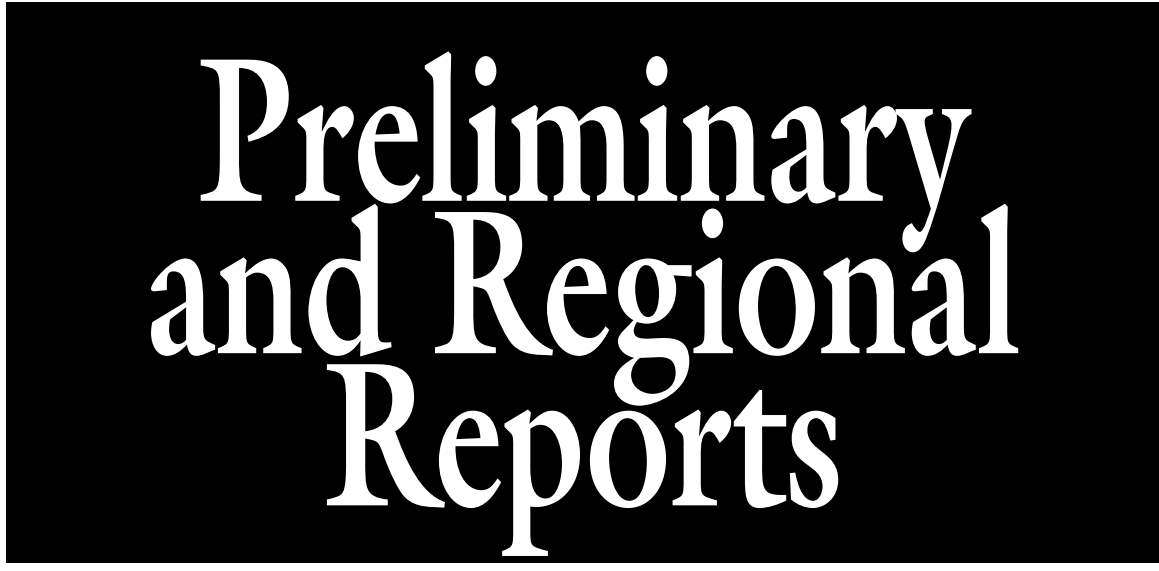

\section{Unique Fruit Development of Ornamental 'Teapot' Jujube}

\author{
Shengrui $\mathrm{Yao}^{1}$
}

AdDitional INDEX wORDs. Ziziphus jujuba, chinese date, flower structure, fruit nutrition

SUMMARY. Jujube or chinese date (Ziziphus jujuba) has fruit that is developed mainly from ovary plus some nectary disk tissue, and the fruit can appear smooth or bumpy on the surface. The objective of this study was to investigate the unique fruit development of ornamental 'Teapot' jujube. Unlike 'Li' and 'Lang', 'Teapot' jujube fruit had one to five protuberances on the shoulder of the fruit and few entirely lack protuberances. The stamens of 'Teapot' jujube flowers were fewer in number, misplaced in location, and deformed in shape-some stamens were anthers only while others were filament only. Deformed stamens of 'Teapot' jujube were always anchored in the nectary disk instead of at their normal location-near the edge of the nectary disk. After bloom, the residue of stamens, nectary disk, and ovary were all constituents of the developing fruit. The deformed stamens developed into the fleshy protuberances and equaled them in number. Fruit with only two pro-

tuberances predominated, which is how the 'Teapot' jujube acquired its name, but the ratio among protuberance categories varied between trees. With its unique and decorative fruit shape, and acceptable fruit quality, 'Teapot' jujube could be used as a backyard tree, both as an ornamental and for its fruit.

$\mathrm{J}$ ujube, also called chinese date or red date, originated in China and has been cultivated for more than 4000 years (Guo and Shan, 2010; Liu, 2006). Jujube together with peach (Prunus persica), plum (Prunus salicina), apricot (Prunus armeniaca), and chinese chestnut (Castanea mollissima) are the five ancient and traditional

Department of Plant and Environmental Sciences, Sustainable Agriculture Science Center at Alcalde, New Mexico State University, Alcalde, NM 87511

The author thanks Steve Guldan, John Mexal, and Geno Picchioni from New Mexico State University for their critical review of the manuscript. The author also acknowledges the editor-in-chief, consulting editor, and three other anonymous reviewers for their constructive comments and suggestions to the previous version of this manuscript. This project is a contribution of the New Mexico Agricultural Experiment Station, New Mexico State University, Las Cruces, NM.

${ }^{1}$ Corresponding author. E-mail: yaos@nmsu.edu. fruit cultivated and recorded in Chinese literature (Liu, 2006). Currently, 99\% of world jujube production is in China, with an annual yield of 2.5 billion kilograms in 2006 (Guo and Shan, 2010; Liu, 2008). There is also some production in South Korea and scattered production in Japan, Russia, Iran, Armenia, Syria, and the Mediterranean regions of France and Spain (Liu, 2008; Locke, 1948; Lyrene, 1979). Jujube adapts to a wide range of soil and weather conditions and is cultivated throughout China except for Heilongjiang and Jilin provinces and Tibet (Liu, 2006).

Jujubes were introduced to the United States from Europe by Robert Chisholm and planted in Beaufort, NC, in 1837 (Rehder and Rixford, 1929; Reich and Arlein, 1991). In 1876, G.P. Rixford brought jujubes from southern France and introduced them to California and nearby states (Rehder and Rixford, 1929). However, those early importations were all seedlings with fruit the size of small olives [Olea europaea (Lyrene and Crocker, 1994)]. The superior, largefruited jujube cultivars were imported into the United States by U.S. Department of Agriculture agricultural explorer Frank N. Meyer beginning in 1908 (Meyer, 1911). People noticed the potential of jujube as a commercial fruit crop, especially for the southwestern United States (Locke, 1948; Meyer, 1916; Thomas, 1927). Since then, jujubes have been planted in many states in the United States, including Alabama, California, District of Columbia, Georgia, Florida, Mississippi, New Mexico, North Carolina, Oklahoma, Pennsylvania, South Carolina, Tennessee, and Texas (Lanham, 1926; Locke, 1948; Yao, 2012). However, for reasons such as lack of research support, promotion, and marketing; propagation hurdles; limited cultivar selection; and lack of an American style jujube product, jujube production is still very limited in the United States (Ashton, 2006; Lyrene, 1979).

In addition to being adapted to a wide range of soil and weather conditions, jujube fruit is nutritious, with an ascorbic acid (vitamin C) content of $200-600 \mathrm{mg} / 100 \mathrm{~g}$ fresh weight, which is 4 to 10 times higher than orange [Citrus sp. (Bi et al., 1990; Proteggente et al., 2002)]. It also contains high amounts of cyclic adenosine monophosphate (Cyong and Hanabusa, 1980; Zhao et al., 2009), antioxidants (Xue et al., 2009), and

\begin{tabular}{llll}
\hline $\begin{array}{l}\text { Units } \\
\text { To convert U.S. to SI, } \\
\text { multiply by }\end{array}$ & U.S. unit & SI unit & $\begin{array}{l}\text { To convert SI to U.S., } \\
\text { multiply by }\end{array}$ \\
\hline 0.3048 & $\mathrm{ft}$ & $\mathrm{m}$ & 3.2808 \\
0.4536 & $\mathrm{lb}$ & $\mathrm{kg}$ & 2.2046 \\
28.3495 & $\mathrm{oz}$ & $\mathrm{g}$ & 0.0353 \\
0.1 & $\mathrm{ppm}$ & $\mathrm{mg} / 100 \mathrm{~g}$ & 10
\end{tabular}


minerals. Jujube fruit traditionally has been used both as fruit and as a traditional Chinese herb (fruit and seeds) (Choi et al., 2011; Mahajam and Chopda, 2009).

There are over 800 jujube cultivars in China (Guo and Shan, 2010), classified as fresh eating, drying, multipurpose (good for both fresh eating and drying), and ornamental. Most jujube cultivars are good backyard trees that can provide pleasant shade and sweet fruit, but some cultivars are more specialized as ornamentals with their unique tree shapes (e.g., Dragon), fruit color, or fruit shapes (Qu and Wang, 1993). 'Chahuzao' is one of the ornamental jujubes from China, and the cultivar name is directly translated as 'Teapot' jujube. It is so named because its fruit shape mimics a mini teapot, with one protuberance as the handle and the other as the spout (Guo and Shan, 2010). The objective of this study was to investigate the unique fruit development of ornamental 'Teapot' jujube.

\section{Materials and methods}

In this experiment, two trees of 1-year-old 'Teapot', as well as 7-yearold 'Li' and 'Lang' with one tree each, were used for this study at New Mexico State University Sustainable Agriculture Science Center at Alcalde, NM (lat. $36^{\circ} 05^{\prime} 27.94^{\prime \prime} \mathrm{N}$, long. $106^{\circ} 03^{\prime} 24.56^{\prime \prime} \mathrm{W}, 5700 \mathrm{ft}$ elevation). A 1-year-old tree of cultivar Jixin was used as a model of jujube flowers. Flower and fruit samples of 'Teapot' and 'Li' were taken regularly and observed microscopically to monitor fruit development.

Fruit soluble solid concentration ( $0 \%$ to $80 \%$ portable refractometer; Sper Scientific, Scottsdale, AZ), vitamin C concentration (dichlorophenolindophenol titration method), and titratable acid concentration were measured when fruit were $80 \%$ to $100 \%$ red for 'Teapot', 'Li', and 'Lang' (Helrich, 1990). Ten to fifteen fruit were combined and used for the analyses. The vitamin $\mathrm{C}$ and titratable acid contents were the average of three repeated measurements. Edible percentage was calculated as the fruit flesh weight divided by the total fruit weight. Fruit of 'Teapot', 'Li', and 'Lang' were tasted in the laboratory at $80 \%$ to $100 \%$ red stage for fresh eating quality based on their flavor, texture, and size. All fruit of 'Teapot' jujube were harvested and sorted by protuberance number and a chi-square test was performed to examine the ratio of each protuberance category between the two trees with Statistix 9 (Analytical Software, Tallahassee, FL).

\section{Results and discussion}

Normal JUJUbe Flower and FRUIT DEVELOPMENT. A typical jujube flower has five separate sepals, five petals, five stamens (which are isomerous with petals), and one ovary with two ovules (Fig. 1A). The petals are yellowish-green, small, inconspicuous, spoon- or cup-shaped, and hold the stamens during the early stage of blooming. The normal jujube fruit from 'Li' and 'Lang' developed mainly from the ovary plus the nectary disk, which also turned green after fruit set and was incorporated into the fruit (Fig. 1B-D). The jujube fruit is therefore not strictly a stone fruit (like peach) that develops from the ovary alone. The remainder of the nectary disk could be seen as a ring on the stem end of the fruit, which indicated nectary disk involvement in fruit development (Fig. 1E). The sepals, petals, and stamens desiccated after bloom and fell off (Fig. IC and D), but not the nectary disks. This conclusion is different from $\mathrm{Ma}$ et al. (2009) who mentioned that fruit of 'Junzao' was the expansion of ovary only.

DEFORMED STAMENS OF 'TEAPOT' JUJUBE FLOWER. For most jujube cultivars, the five stamens were evenly attached to the edge of the nectary disk between the sepals and aligned with the base of each petal (Fig. 2A). However, for 'Teapot', stamens were deformed at the flower bud differentiation stage, and even some of the petals were deformed and mislocated (Fig. 2B). The tops of mature 'Teapot' flower buds were more pointed, not as flat as 'Li' and 'Lang', and they also had larger petals with edges that were not as smooth as 'Li' or 'Lang'.

Most 'Teapot' flowers did not have five stamens, but varied from one to five in number. Some stamens had only filaments without anthers, whereas others were anthers directly attached to the nectary disk close to the ovary without elongated filaments (Fig. 2B, 2D-F). It was rare that a 'Teapot' flower had stamens located in the normal location at the edge of nectary disk with petals [Fig. 2C (lower flower)] - most of them were anchored in the nectary disk (Fig. 2D-F). Occasionally, 'Teapot' flowers had only one or two stamens that were located in the normal position at the edge of the nectary disk; those stamens then withered after anthesis, and the flower developed into a fruit of normal shape without protuberances (Fig. 2G and $\mathrm{H}$ ).

'TEAPOT' FRUIT DEVELOPMENT. After bloom, the anthers of the deformed stamens withered and the remaining stamens, including the stamen residue with desiccated anthers, which were anchored in the nectary disk, together with the ovary and the nectary disk, turned green after fruit set and were all involved in fruit development (Fig. 3) because there are meristem tissues in both the ovary and the nectary disk (Guo and Shan, 2010). The fleshy protuberances were derived from the residue of deformed stamens as previously reported (Ma et al., 2009). The number of fleshy protuberances was the same as the number of stamens (with or without anthers) in the nectary disk (Fig. 3A-E). The stamens with anthers developed into the larger bumps on the fruit surface with vesicular bundle scar, and the filament-only stamens developed into the protuberances with sharp points or backward hooks in young fruit (Fig. 3A2 and B3).

Mature 'Teapot' fruit shapes AND FRUIT QUALITY. Fruit of 'Li' and 'Lang' did not have any protuberances/appendices on the fruit surface, but 'Teapot' fruit had one to five protuberances at the stem end of the fruit (Fig. 4). The length of the protuberance was normally one-fourth to one-half of the fruit body length, but could extend to two-thirds or more of the fruit surface.

In general, fruit with two protuberances were the most dominant, which is how the cultivar gets its name, but the percentage for each category was not fixed and varied by tree (Table 1 ). One tree had seven fruit with five protuberances while the other had no fruit with five protuberances and even fruit with four protrusions were not common (Table 1). A chi-square test indicated that the ratio of each protuberance category was different between the two trees and the reason for this is unknown. 

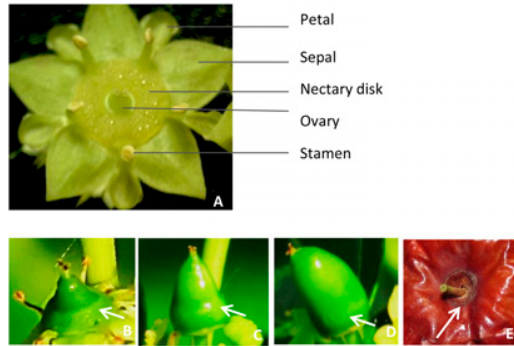

Fig. 1. 'Li' jujube flower and its fruit development process: (A) flower, (BD) fruit development process (arrows indicate tissue developed from nectary disk), (E) nectary disk ring (arrow) in mature fruit.

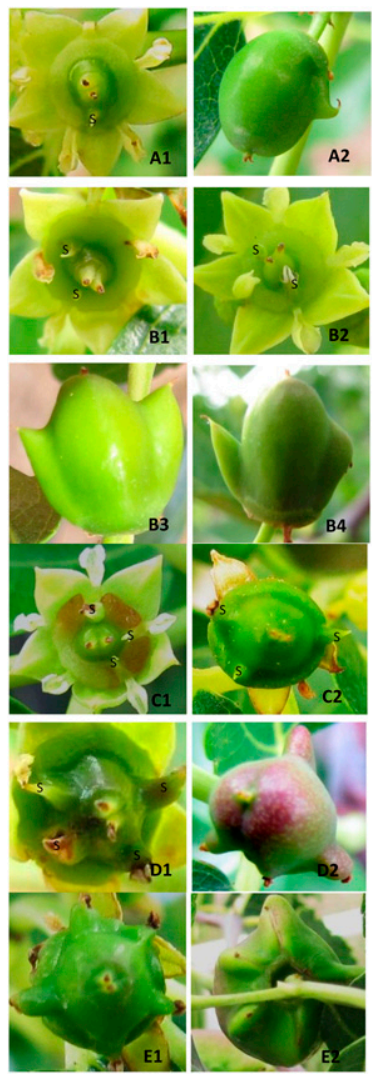

Fig. 3. 'Teapot' jujube flowers or fruitlets with one to five stamens / protuberances showing the diversity of fruit and their development. Because of the low fruit set of jujube, most of them were not consecutive pictures of the same flower; (A1-A2) Flowers/ fruitlets with one stamen or one protuberance, (BI-B4) flowers / fruitlets with two stamens or two protuberances, (C1-C2) flowers/ fruitlets with three stamens or three protuberances, (D1-D2) flowers / fruitlets with four stamens or four protuberances, (E1-E2) flowers/ fruitlets with five stamens or five protuberances $(s=$ stamen with or without anther).
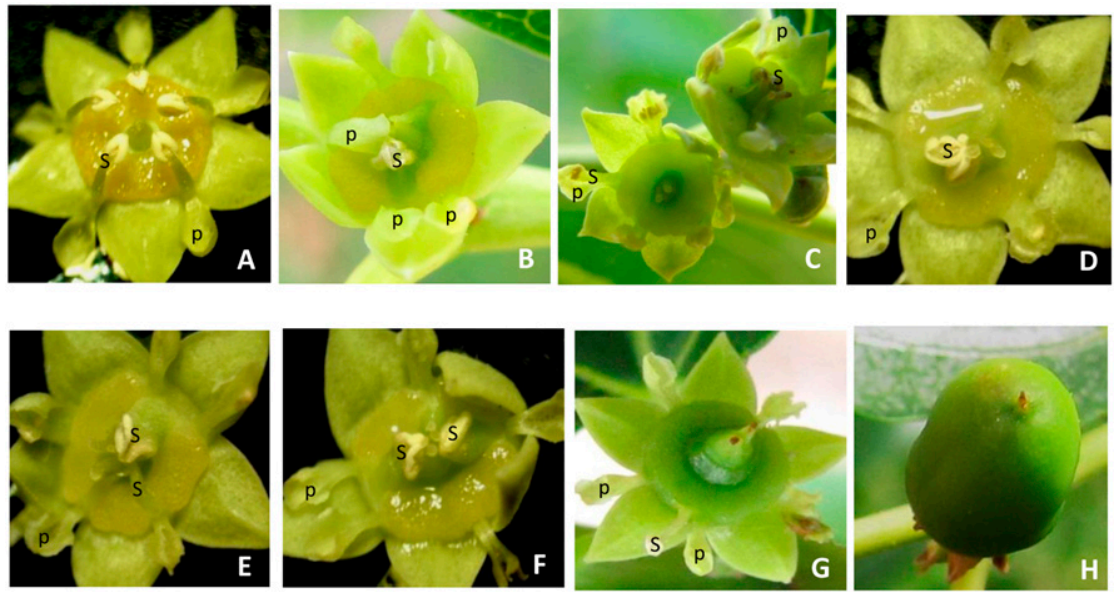

Fig. 2. 'Jixin' and 'Teapot' jujube flowers with normal and deformed stamen configurations: (A) a typical jujube flower (cultivar Jixin) with five petals located between the sepals and five stamens attached to the edge of the nectary disk, same location as each petal; (B) 'Teapot' flower with misplaced petals and deformed stamens anchored near the stigmas in the nectary disk; (C) 'Teapot' flower with stamens near the petals at the edge of the nectary disk (lower flower) and with stamens gathered around stigmas (upper flower); (D-F) shortened stamens of 'Teapot' with or without anthers anchored in the nectary disk, close to stigmas; $(G)$ 'Teapot' flower with one stamen located near the edge of the nectary disk (only one but at normal location); (H) 'Teapot' flower from $(G)$ developed into a normal looking fruit ( $\mathrm{p}=$ petal, $\mathrm{s}=$ stamen with or without anther).
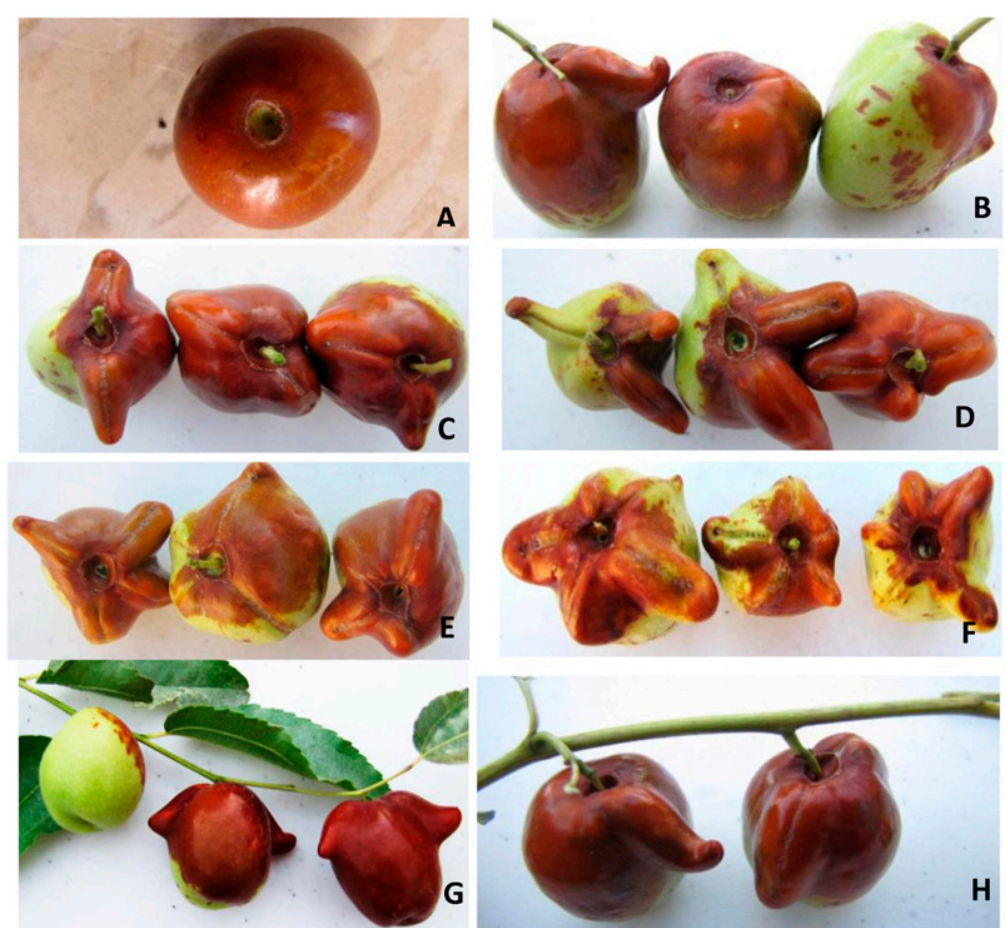

Fig. 4. 'Teapot' jujube fruit with zero to five protuberances on the fruit surface: (A) fruit without protuberance, $(B)$ fruit with one protuberance, $(C)$ fruit with two protuberances, (D) fruit with three protuberances, (E) fruit with four protuberances, $(F)$ fruit with five protuberances, $(G$ and $H)$ fruit on the branchlets.

Unlike other cultivars with a ring on the stem end of the fruit as the remainder of the nectary disk, the "ring" of 'Teapot' was bigger than other cultivars and was stretched to an angular shape for most 'Teapot' fruit (Fig. 4B-H). This indicated that those deformed stamens anchored in the 
Table 1. 'Teapot' jujube fruit protuberance number and percentage in 2012 at Alcalde, NM.

\begin{tabular}{lccccc}
\hline & \multicolumn{2}{c}{ Tree 1 } & & \multicolumn{2}{c}{ Tree 2 } \\
\cline { 2 - 3 } \cline { 5 - 6 } Protuberance (no.) & 2 & 1.5 & & 8 & 8.0 \\
0 & 17 & 12.7 & & 32 & 32.0 \\
1 & 49 & 36.6 & & 38 & 38.0 \\
2 & 38 & 28.4 & & 20 & 20.0 \\
3 & 21 & 15.7 & & 2 & 2.0 \\
4 & 7 & 5.2 & & 0 & 0.0 \\
5 & 134 & 100 & & 100 & 100 \\
Total & & & & \\
\hline
\end{tabular}

Table 2. Basic fruit quality characteristics of jujube cultivars Li, Lang, and Teapot with fruit of $80 \%$ to $100 \%$ red color in 2012 at Alcalde, NM.

\begin{tabular}{|c|c|c|c|c|c|}
\hline \multirow[b]{2}{*}{ Cultivar } & \multirow{2}{*}{$\begin{array}{c}\text { Fruit } \\
\text { wt }(g)^{z}\end{array}$} & $\underline{\text { Vitamin } C(\mathrm{mg} / 100 \mathrm{~g})^{\mathrm{z}}}$ & Titratable acid (\%) & \multirow{2}{*}{$\begin{array}{c}\text { Soluble } \\
\text { solids (\%) }\end{array}$} & \multirow{2}{*}{$\begin{array}{c}\text { Edible } \\
(\%)\end{array}$} \\
\hline & & \multicolumn{2}{|c|}{ mean $\pm S D$} & & \\
\hline $\mathrm{Li}$ & 23.2 & $283.9 \pm 2.2$ & $0.30 \pm 0.01$ & 23.0 & 97.7 \\
\hline Lang & 21.6 & $372.2 \pm 4.3$ & $0.34 \pm 0.02$ & 27.3 & 93.7 \\
\hline Teapot & 5.5 & $306.4 \pm 1.2$ & $0.56 \pm 0.01$ & 28.0 & 93.8 \\
\hline
\end{tabular}

${ }^{z_{1}} \mathrm{~g}=0.0353 \mathrm{oz}, 1 \mathrm{mg} / 100 \mathrm{~g}=10 \mathrm{ppm}$.

nectary disk were involved in fruit development, and only 'Teapot' fruit without any protuberance kept the remaining nectary disk in circular shape (Fig. 4A).

The 'Teapot' jujube fruit with $80 \%$ to $100 \%$ red color on 1-year-old shoots had $28 \%$ soluble solid content, $306 \mathrm{mg} / 100 \mathrm{~g}$ fresh weight vitamin $\mathrm{C}$ content, and $0.56 \%$ titratable acid (Table 2). Its soluble solid content was similar to 'Lang' and higher than 'Li', and it had higher titratable acid content than both 'Li' and 'Lang'. However, 'Teapot' fruit size was much smaller than the other two cultivars. Overall, its fresh eating quality was acceptable but not as good as ' $\mathrm{Li}$ ' and 'Lang'. The pit (kernel) was 0.3$0.4 \mathrm{~g}$ and flat in shape with no seed inside, as reported by Guo and Shan (2010).

'Teapot', 'Dragon', and 'Gourd' are the dominant specialized ornamental jujubes in China ( $\mathrm{Qu}$ and Wang, 1993). 'Teapot' has been planted as an ornamental in several counties in Shandong Province, China, for over 100 years (Guo and Shan, 2010). A mature 'Teapot' tree in China can grow to $20 \mathrm{ft}$ tall with a natural spherical shape and spreading branches. 'Teapot' jujube can adapt to a wide range of soil conditions just as other jujube cultivars do (Guo and Shan, 2010). It set fruit during the grafting year at Alcalde, NM. Ma et al. (2009) reported that 'Teapot' had the highest fruit set for the 11 cultivars compared at natural pollination conditions. With its unique fruit shape, reasonable fruit quality, and good fruit set, 'Teapot' could be a dual backyard ornamental tree for both fruit and decoration in the United States. To determine the suitable growing areas for 'Teapot', a regional cultivar trial is needed before recommendations can be made. In addition, it should be noted that jujubes in general could be invasive with root suckers, especially in humid, high rainfall areas; it is less problematic under arid weather conditions.

\section{Literature cited}

Ashton, R. 2006. Jujube: The chinese date. Third Millennium Publ., Tempe, AZ.

Bi, P., Z. Kang, F. Lai, and X. Lu. 1990. Fruit vitamin $\mathrm{C}$ content changes of different jujube cultivars (in Chinese). Shanxi Fruit 4:24-25.

Choi, S.H., J.B. Ahn, N. Kozukue, C.E. Levin, and M. Friedman. 2011. Distribution of free amino acids, flavonoids, total phenolics, and antioxidative activities of jujube (Ziziphus jujuba) fruit and seeds harvested from plants grown in Korea. J. Agr. Food Chem. 59:65946604.

Cyong, J. and K. Hanabusa. 1980. Cyclic adenosine monophosphate in fruits of Zizyphus jujuba. Phytochemistry 19: 2747-2748.
Guo, Y. and G. Shan. 2010. The chinese jujube. Shanghai Scientific Technical Publishers, Shanghai, China. (in Chinese).

Helrich, K. 1990. Official methods of analysis of the association of official analytical chemists. 15th ed. Assn. Official Analytical Chemists, Arlington, VA.

Lanham, W.B. 1926. Jujubes in Texas. Texas Agr. Expt. Sta. Circ. No. 41.

Liu, M. 2006. Chinese jujube: Botany and horticulture. Hort. Rev. 32:229298.

Liu, M. 2008. China jujube development report. China Forestry Publishing House, Beijing, China. (in Chinese).

Locke, L.F. 1948. The chinese jujube: A promising fruit tree for the southwest, $\mathrm{p}$. 78-81. In: Oklahoma crops and soils, 1947: Research reported at the Second Annual Oklahoma Crops and Soils Conference. Oklahoma Agr. Expt. Sta. Bul. B319.

Lyrene, P.M. 1979. The jujube tree. Fruit Var. J. 33:100-104.

Lyrene, P.M. and R.E. Crocker. 1994. The chinese jujube. Univ. Florida Coop. Ext. Serv. Fact Sheet HS-50.

Ma, G., H. Chen, Z. Shen, and J. Zhang. 2009. Morphological observation of diversity fruit shape in Chahuzao variety of chinese jujube (in Chinese). J. Shanxi Agr. Sci. 37:9-12.

Mahajam, R.T. and M.Z. Chopda. 2009. Phyto-pharmacology of Ziziphus jujuba Mill-A plant review. Pharmacognosy Rev. 3:320-329.

Meyer, F.N. 1911. Agricultural explorations in the fruit and nut orchards of China. U.S. Dept. Agr., Bur. Plant Ind. Bul. 204. 28 Dec. 2012. <http://books.google.com/ books? $\mathrm{id}=\mathrm{GqQUAAAAYAAJ} \&$ printsec $=$ frontcover\&source $=g b s \_g e \_s u m m a r y \_r \&$ $\mathrm{cad}=0 \# \mathrm{v}=$ onepage $\& \mathrm{q} \& \mathrm{f}=$ false $>$.

Meyer, F.N. 1916. China a fruitful field for plant exploration, p. 205-224. In: USDA yearbook of agriculture 1915. 28 Dec. 2012. <http://naldc.nal. usda.gov/download/IND43843025/ PDF $>$.

Proteggente, A.R., A.S. Pannala, G. Paganga, L. van Buren, E. Wagner, S. Wiseman, F. van de Put, C. Dacombe, and C.A. Rice-Evans. 2002. The antioxidant activity of regularly consumed fruit and vegetables reflects their phenolic and vitamin C composition. Free Radic. Res. $36: 217-233$.

Qu, Z. and Y. Wang (eds.). 1993. Chinese fruit tree record- Chinese jujubes. China 


\section{Preliminary and Regional Reports}

Forestry Publishing House, Beijing, China. (in Chinese).

Rehder, A. and G.P. Rixford. 1929. Zizyphus, p. 3547-3548. In: L.H. Bailey (ed.). The standard cyclopedia of horticulture. MacMillan, New York, NY.

Reich, L. and V.H. Arlein. 1991. Uncommon fruit worthy of attention: A gardener's guide. Addison-Wesley, Boston, MA.
Thomas, C.C. 1927. Chinese jujube in southwestern United States, p. 212 215. In: USDA yearbook of agriculture 1926. 28 Dec. 2012. <http://naldc.nal. usda.gov/download/IND43842740/ PDF $>$.

Xue, Z., W. Feng, J. Cao, D. Cao, and W. Jiang. 2009. Antioxidant activity and total phenolic contents in peel and pulp of chinese jujube (Ziziphus jujuba Mill.) fruit. J. Food Chem. 33:613-629.
Yao, S. 2012. Jujube: Chinese date in New Mexico. New Mexico State Univ. Coop. Ext. Publ. H-330.

Zhao, A., D. Li, Y. Wang, C. Sui, Y. Cao, and Q. Liang. 2009. Study on the contents of cAMP and cGMP in different cultivars, growing periods and organs in chinese jujube (in Chinese). Acta Hort. Sinica 36:1134-1139. 